\title{
CONDITION ASSESMENT OF GLENDENG BRIDGE USING BRIDGE MANAJEMENT SYSTEM (BMS) IN TUBAN DISTRICT
}

\author{
Ahmad Faathir Wicaksono ${ }^{1}$, Ratna Handayani ${ }^{2}$ \\ 1,2 Junior Road and Bridge Engineer, East Java Province Road Agency, Surabaya, Indonesia \\ E-mail: faathirahmad@gmail.com
}

\begin{abstract}
The valuation of Glendeng Bridge condition in Tuban District is needed to evaluate the deterioration of the bridge caused by the Bengawan Solo river flooding since the high rainfall which was made worst by the excavation of the bridge protection structure. This research is conducted through the direct visual survey by recorded the detail element of the bridge deterioration based on the deterioration code and assessed the level of severity and structural condition whether the element affecting the other element and suffering the overall bridge condition. This valuation of the bridge is based on the Bridge Management System (BMS) which was being studied by the Pusjatan Ministry of Public Work in 2012.

The research shows that the main element deteriorated was the approach embankment, retaining wall, rubber bearing and earthquake dump isolator on the north side of Tuban caused by the drainage on the surface, excavation of the front of approach road and the flooding of Bengawan Solo river. The overall condition of the bridge is valuated with 4 (four) mark so that the bridge is needed to have the strengthening and replacement on the deteriorate elements
\end{abstract}

Keywords: Bridge Manajement System, Glendeng, Condition Number, Truss Bridge, Approach Road

\section{Introduction}

The inspection of Glendeng Bridge condition is conducted to investigate the overall bridge condition ensuring the safety of the bridge used by the traffic users. The Glendeng bridge condition had the embankment defect since the Bengawan Solo River flooding which was made worst by the excavation of the bridge protection structure. This inspection process is performed to follow up the public report as the temporary closing of Glendeng Bridge for all of vehicle type and redirected the traffic of Tuban - Bojonegoro through Kali Ketek Bridge of Ponco - Jatirogo road. This inspection is conducted using the condition assessment based on the Bridge Management System (BMS) which had been studied by Pusjatan Ministry of Public Work at 2012.

The current situation at Glendeng Bridge Jembatan Glendeng had been totally closed since the danger and harmful condition for the road user caused by the erosion of Bengawan Solo River, the fast response of temporary prevention and repairing are needed by using the strengthen of the belt in north side of the bridge[1]. The main cause of the decreasing embankment stability was the river flow regime[2], the defect of the abutment and embankment caused by the flooding had been studied which revealing that the maximum debit influencing the turbulence current causing the local scouring and damaging the abutment footing [3]. The purpose of bridge inspection is to ensure the bridge condition secure functionally and planning the certain work for maintenance and periodic repairing [4]. The detail bridge inspection of Glendeng Bridge is conducted to assess the overall condition of each bridge element. The research of bridge assessment using the Bridge Management System (BMS) had been conducted for 4 bridges in Aceh Province, the result shows that the BMS and Bridge Condition Rating (BCR) proposed the same treatment of repairing [5]. The BMS is used in DIY 
province where 4 bridges had been assessed and most of them are affected by the river stream flow [6]. The Glendeng Bridge is categorized as truss bridge with the length about 300 meters, the similar research using BMS to assess the bridge condition had been conducted on the Kapuas Bridge with the length 250 meters which marked with 1 resulting on the routine maintenance [7]. The BMS in East Java Province had been used for bridge in Greater Surabaya by integrating the BMS and NYSDOT resulting on the repairing rank and proposing 4 bridge that need to have the replacement [8].The NYSDOT using BCR method differs comparing to BMS, the BCR uses the 9 component rating and 13 weighting component [9]. The ultimate goal of this research is to find out the type and severe level of the of each deteriorated bridge element using the Bridge Management System (BMS) and proposed the repairing work need.

\section{Material and Method}

\subsection{Description of Research Location}

Glendeng Bridge is located at Jalan Tuban - Bojonegoro road which authorized by the Tuban Local District Government, the detail data of Glendeng Bridge is shown below:
Name
: GLENDENG BRIDGE
Road
: Bojonegoro - Tuban Road
Length
: 300 meters $(5 \times 60)$
Superstructure
: Australia Truss Bridge (B 60)
Substructure
: 2 abutment sand 3 piers
Foundation
: Steel Pile Diameter $60 \mathrm{~cm}$
Built
: 1990
Status
: Tuban District

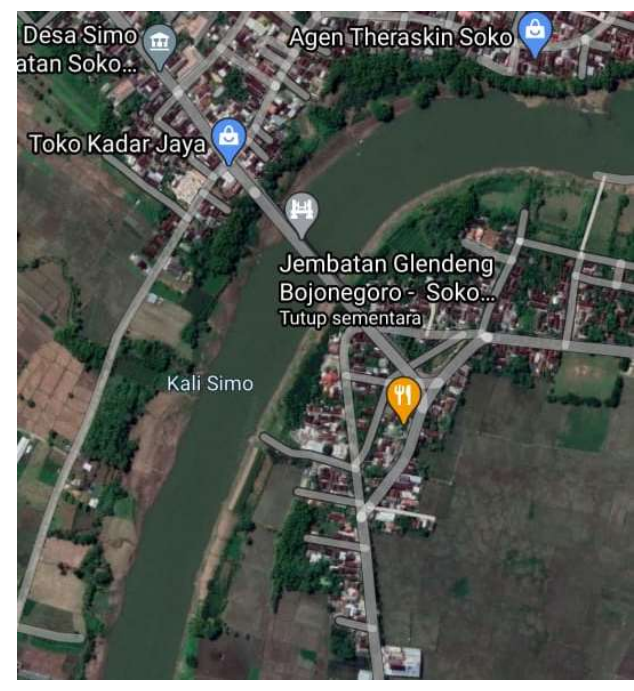

Figure 1. Glendeng Bridge Location

(Source: maps.google.com) 


\section{JICEJournal Innovation of Civil Engineering}

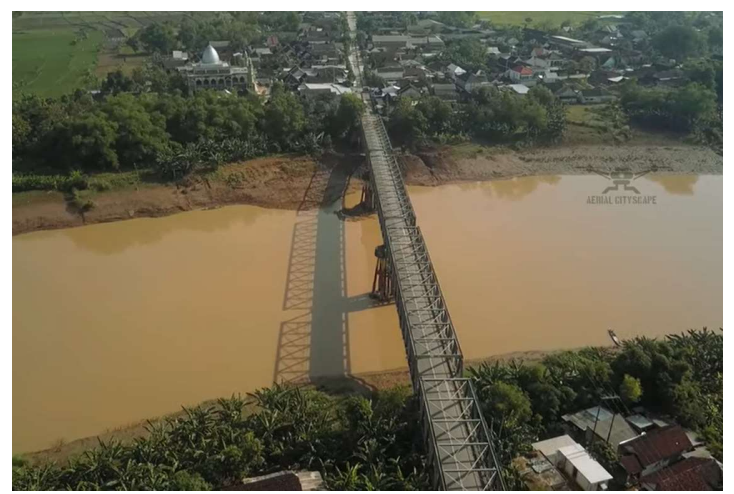

Figure 2. Glendeng Bridge Condition

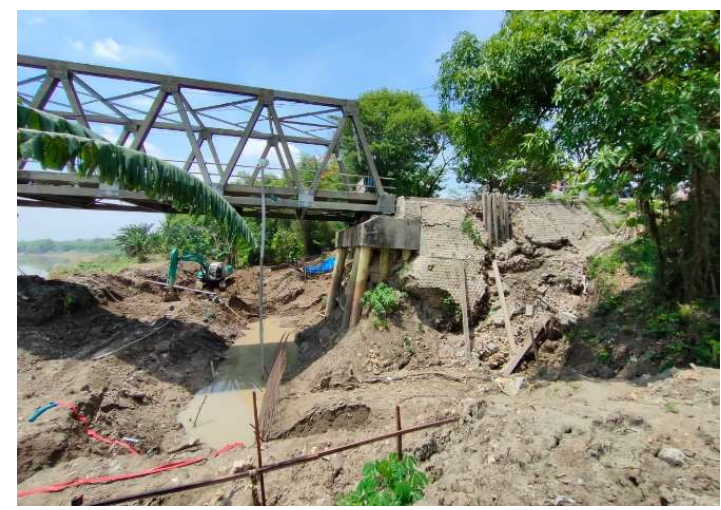

Figure 3. Embankment Defect Condition of Glendeng Bridge at Tuban District Side

\subsection{Research Flow Chart}

This research is conducted by surveying each defect elements and recording based on the defect code. The defect element is assessed the harmful level and structural condition whether they influence the other element and harming the entire bridge condition. The flow chart of the research is shown below. 


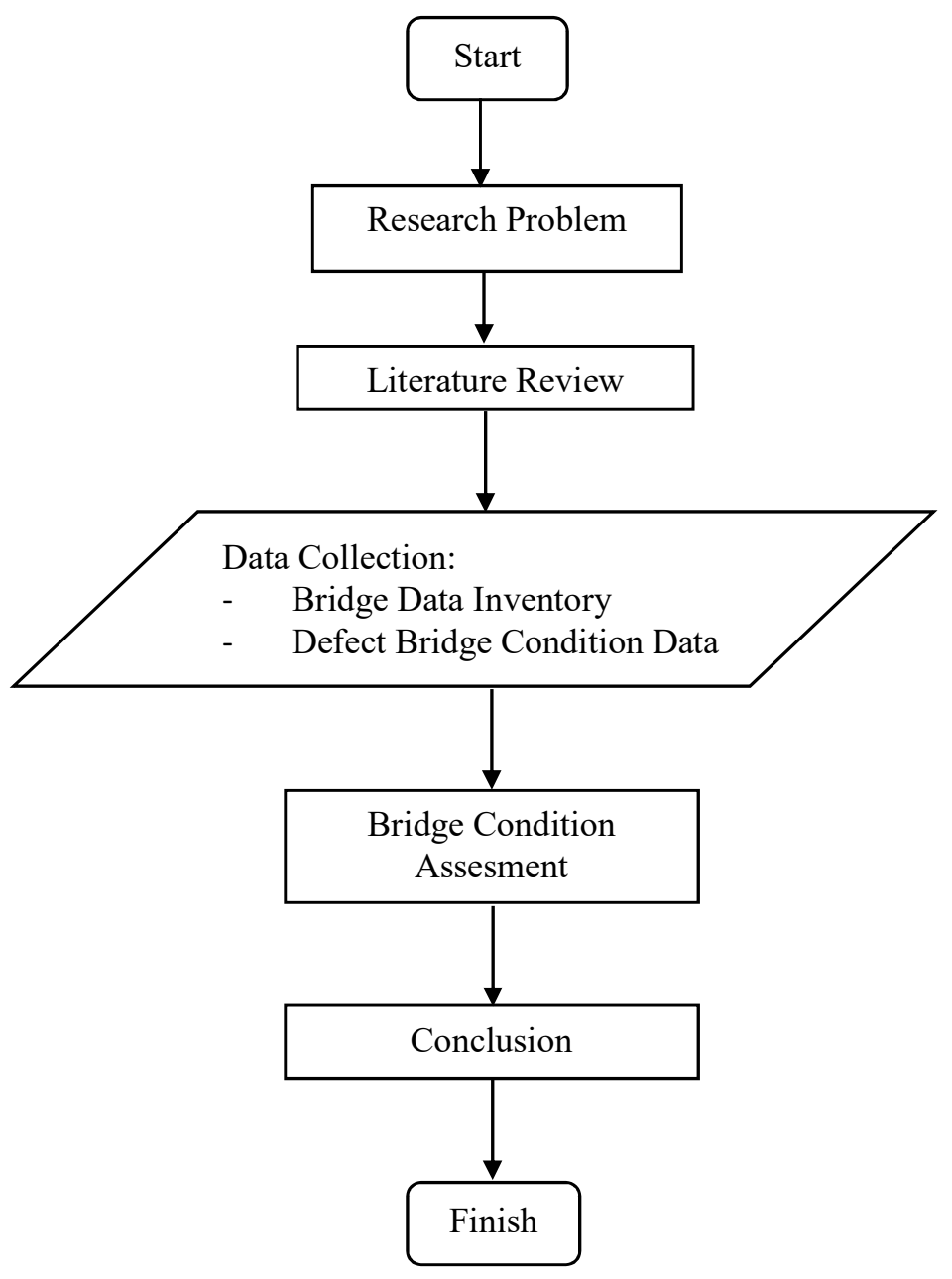

Figure 4. Research Flow Chart

\section{Result and Discussion}

\subsection{Primary Bridge Defect}

The primary bridge defect is seen at the embankment at the north side of Tuban. The erosion and settlement on the embankment is detected, this condition is affected by the surface drainage flooding the left and right side of the embankment combined with the high of surface water level of Bengawan Solo River in the November 2020. The landslide and erosion is triggered by the excavation at the in front of side of embankment causing the passive soil resistance is less making the embankment shifts and push the abutment and pile of the bridge. 


\section{JCEJournal Innovation of Civil Engineering}

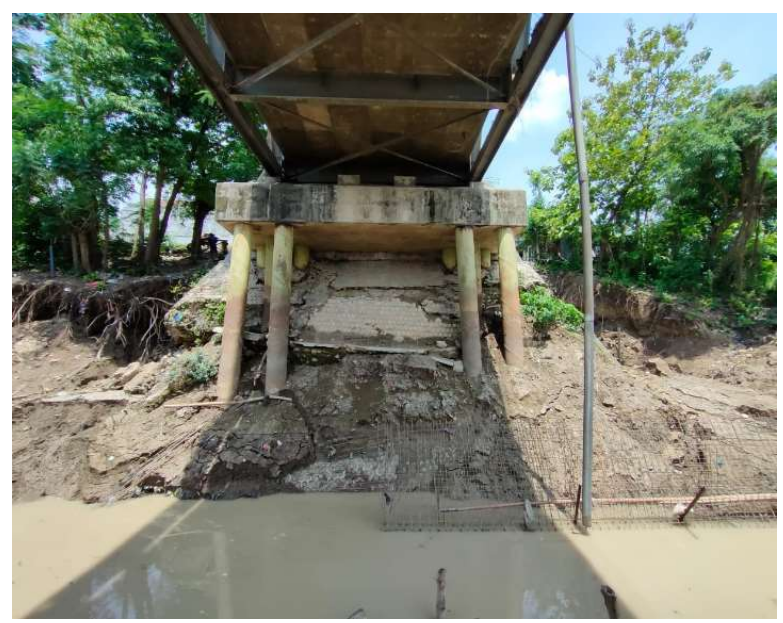

Figure 5. Erosion of embankment caused by the high water level of river and excavation

The defect of the embankment is harmful and potentially affecting the other bridge structure such as abutment and the superstructure.

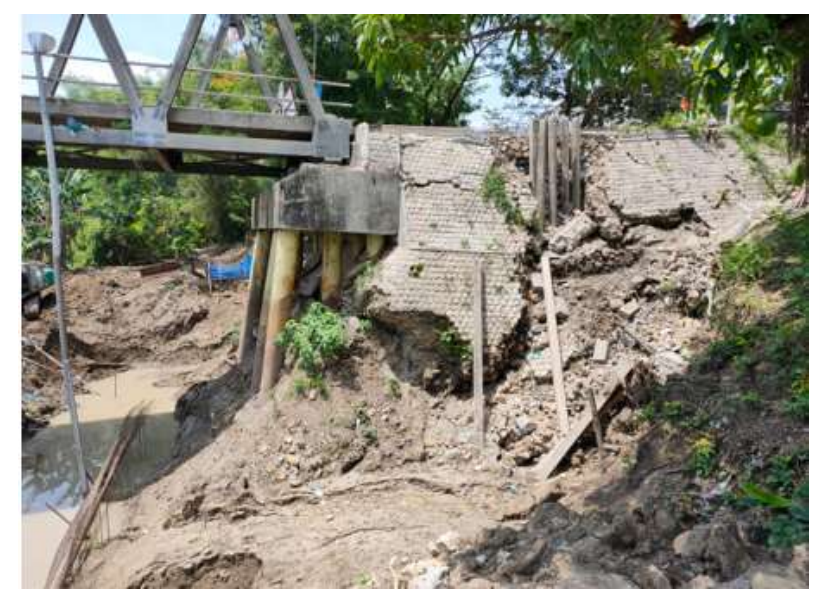

Figure 6. Shifting of abutment caused by the erosion of embankment pushing the pile

The defect mechanism of the embankment is triggered by the excavation in front of the embankment about $9,5 \mathrm{~m}$ causing the active soil resistance stresses and pushes the pile and abutment 


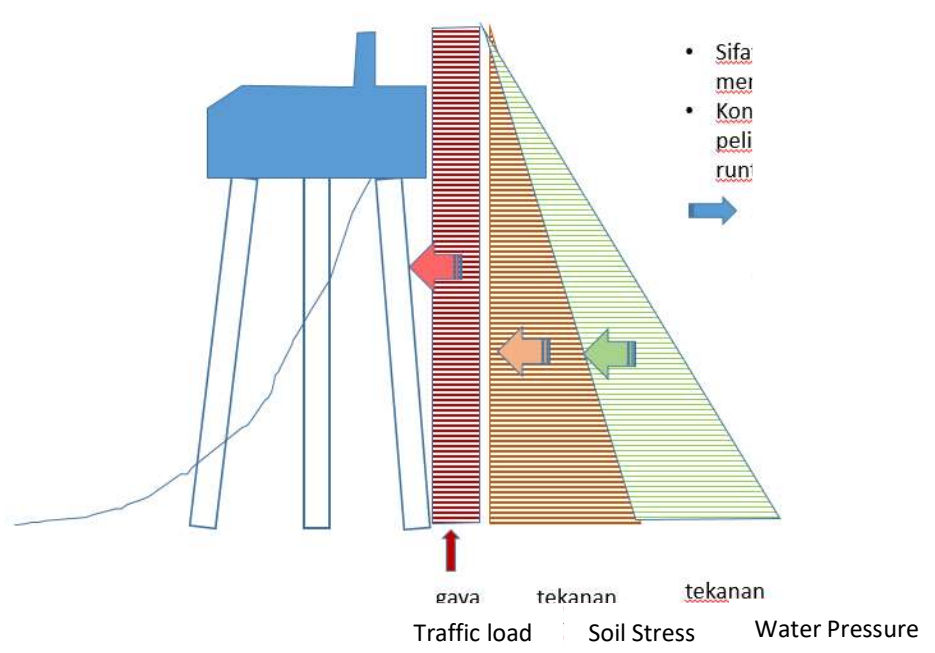

Figure 7. Embankment defect mechanism at Glendeng Bridge

The other main defect which was influenced by the shifting of the abutment caused by the erosion of embankment is the rubber bearing and earth restraint block of the abutment at the north side of Tuban. The excessive movement of the rubber bearing $>10 \mathrm{~cm}$ shows that there is a movement at the substructure or foundation [10].

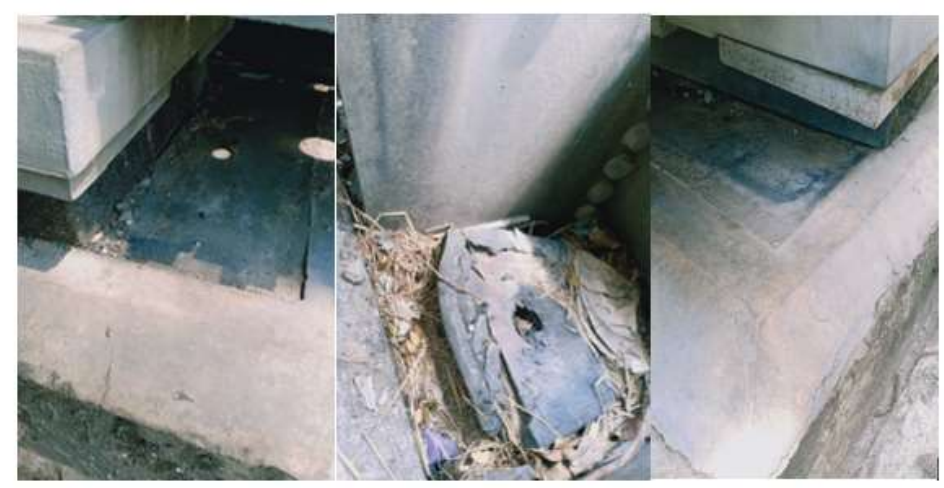

Figure 8. Rubber bearing movement $>10 \mathrm{~cm}$ and earth restraint block deformation

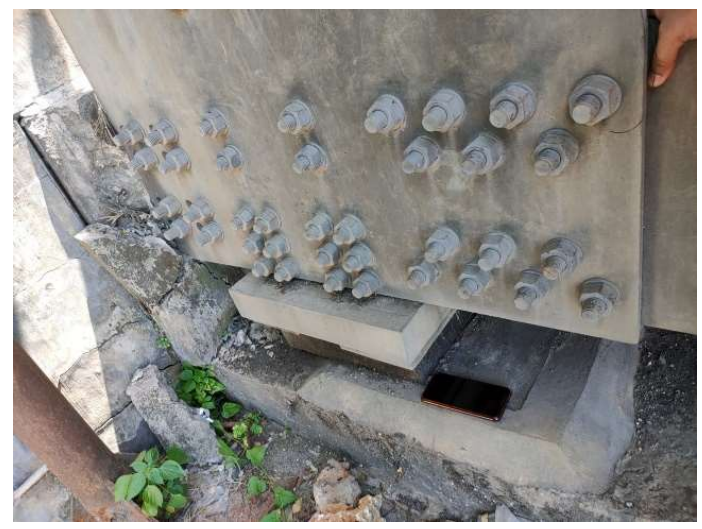

Figure 9. Rubber bearing movement $10-20 \mathrm{~cm}$ influences the backwall 


\subsection{Assessment of Bridge Condition}

The result of the assessment on the defect bridge element at level 5 and level 3-4 shows that the defect of embankmen and the retaining wall is given the 5 mark so that the repairing is needed as quick as possible because it will influence the other element especially the superstructure of truss bridge and pile. The defect of rubber bearing and earth restraint block can be fixed by changing this element with the new one.

Table 7. Assessment of Bridge Condition at Level 5 and Level 3-4

\begin{tabular}{|c|c|c|c|c|c|c|c|c|c|c|c|c|c|c|c|c|c|c|c|}
\hline \multicolumn{2}{|c|}{ Defective Element } & \multicolumn{2}{|r|}{ Defect } & \multirow{2}{*}{\multicolumn{4}{|c|}{ Location }} & \multirow{2}{*}{\multicolumn{6}{|c|}{$\frac{\text { Level } 5}{\text { Condition }}$}} & \multirow{2}{*}{\multicolumn{6}{|c|}{$\begin{array}{c}\text { Level } 3 \text { - } 4 \\
\text { Condition }\end{array}$}} \\
\hline \multirow{2}{*}{ Code } & \multirow{2}{*}{ Description } & \multirow{2}{*}{ Code } & \multirow{2}{*}{ Description } & & & & & & & & & & & & & & & & \\
\hline & & & & $\mathrm{A} / \mathrm{P} / \mathrm{B}$ & $\mathrm{x}$ & $\mathrm{Y}$ & Z & $\mathrm{S}$ & $\mathrm{R}$ & $\mathrm{K}$ & $\mathrm{F}$ & $\mathrm{P}$ & NK & $\mathrm{S}$ & $\mathrm{R}$ & $\mathrm{K}$ & $\mathrm{F}$ & $\mathrm{P}$ & NK \\
\hline \multirow[t]{2}{*}{4.231} & $\begin{array}{l}\text { Approach } \\
\text { Embankment }\end{array}$ & 521 & Scour & A1 & & & & & & & & & & 1 & 1 & 1 & 1 & 1 & 5 \\
\hline & & & & & & & & & & & & & & & & & & & \\
\hline 4.227 & $\begin{array}{l}\text { Retaining } \\
\text { Wall }\end{array}$ & 511 & $\begin{array}{l}\text { Missing } \\
\text { Material }\end{array}$ & A1 & & & & & & & & & & 1 & 1 & 1 & 1 & 1 & 5 \\
\hline \multirow[t]{2}{*}{4.321} & Pile Cap & 551 & Movement & A1 & & & & & & & & & & 1 & 0 & 0 & 0 & 1 & 2 \\
\hline & & & & & & & & & & & & & & & & & & & \\
\hline \multirow[t]{4}{*}{4.326} & $\begin{array}{l}\text { Earthquake } \\
\text { Restraint } \\
\text { Block }\end{array}$ & 561 & $\begin{array}{l}\text { Loose or } \\
\text { missing } \\
\text { element }\end{array}$ & A1 & 1 & & & 1 & 0 & 0 & 0 & 1 & 2 & & & & & & \\
\hline & & & & & 2 & & & 1 & 1 & 1 & 1 & 1 & 5 & & & & & & \\
\hline & & & & $\mathrm{P} 1$ & 1 & & & 1 & 0 & 0 & 0 & 1 & 2 & & & & & & \\
\hline & & & & & 2 & & & 1 & 0 & 0 & 0 & 1 & 2 & & & & & & \\
\hline \multirow[t]{2}{*}{4.612} & \multirow{2}{*}{$\begin{array}{l}\text { Rubber } \\
\text { bearing }\end{array}$} & \multirow[t]{2}{*}{604} & \multirow{2}{*}{$\begin{array}{l}\text { Excessive } \\
\text { movement } \\
\text { or } \\
\text { deformation }\end{array}$} & A1 & 1 & & & 1 & 1 & 1 & 1 & 1 & 5 & & & & & & \\
\hline & & & & & 2 & & & 1 & 1 & 1 & 1 & 1 & 5 & & & & & & \\
\hline
\end{tabular}

Table 8. Assessment of Bridge Condition at Level 3

\begin{tabular}{|l|l|c|c|c|c|c|c|}
\hline \multicolumn{2}{|c|}{ LEVEL 3 } & \multicolumn{6}{c|}{ Condition Mark } \\
\hline Code & \multicolumn{1}{|c|}{ Element } & S & R & K & F & P & NK \\
\hline 3.210 & Waterway & 1 & 1 & 1 & 0 & 1 & 4 \\
\hline 3.220 & Scour Protection & 1 & 1 & 0 & 1 & 1 & 4 \\
\hline 3.230 & Embankments & 1 & 1 & 0 & 1 & 1 & 4 \\
\hline 3.310 & Foundations & & & & & & \\
\hline 3.320 & Abutment/Piers & 1 & 1 & 0 & 1 & 1 & 4 \\
\hline 3.420 & Flat Slab & & & & & & \\
\hline 3.430 & Arch & & & & & & \\
\hline 3.440 & Beam Arch & & & & & & \\
\hline 3.450 & Trusses & & & & & & \\
\hline 3.480 & Suspension System & & & & & & \\
\hline 3.500 & Deck System & & & & & & \\
\hline 3.600 & Deck Joints & & & & & & \\
\hline 3.610 & Bearings & 1 & 1 & 0 & 1 & 1 & 4 \\
\hline 3.620 & Railing & & & & & & \\
\hline 3.700 & Furniture & & & & & & \\
\hline 3.80 & Culvert & & & & & & \\
\hline
\end{tabular}


Table 9. Assessment of Bridge Condition at Level 2

\begin{tabular}{|c|l|c|c|c|c|c|c|}
\hline \multicolumn{2}{|c|}{ LEVEL 2 } & \multicolumn{7}{|c|}{ Condition Mark } \\
\hline Code & \multicolumn{1}{|c|}{ Element } & S & R & K & F & P & NK \\
\hline 2.200 & Waterway/Embankment & 1 & 1 & 1 & 0 & 1 & 4 \\
\hline 2.300 & Substructure & 1 & 1 & 0 & 0 & 1 & 3 \\
\hline 2.400 & Superstructure & 0 & 0 & 0 & 1 & 1 & 2 \\
\hline 2.800 & Culvert & 0 & 0 & 0 & 0 & 0 & 0 \\
\hline 2.900 & Wet Crossing & 0 & 0 & 0 & 0 & 0 & 0 \\
\hline
\end{tabular}

Table 10. Assessment of Bridge Condition at Level 1

\begin{tabular}{|c|c|c|c|c|c|c|c|}
\hline \multicolumn{2}{|c|}{ LEVEL 1 } & \multicolumn{5}{c|}{ Condition Mark } \\
\hline Code & Element & S & R & K & F & P & NK \\
\hline 1.000 & Bridge & 1 & 1 & 0 & 1 & 1 & 4 \\
\hline
\end{tabular}

The overall mark of the bridge is 4 , the retrofitting and replacement of the defect element is the primary target since the defect is affected by water current of Bengawan Solo River which can be predicted when the flooding occur. The alternative repairing to prevent the further defect is shown below:

a) Discarding /decreasing the active soil resistance which pushing the abutment and pile with the following step as follows:

- Installing the sheetpile around the embankment;

- Discarding the soil at the embankment by constructing the new approach bridge;

- Changing the embankment material using the lighter material or foam mortar

- New material for embankment strengthen with the geotextile;

b) Restoring the passive soil resistance in front of the embankment with the following step as follows:

- Installing the gabion in front of the current on going retaining wall;

- Embankment pile technology

c) Preventing the scouring by using the cribs.

d) Structural health monitoring is needed to check the superstructure condition.

e) The defect of superstructure can be retrofitted by:

- Backwall retrofitting,

- Rubber bearing and earth restraint block replacement,

- Strengthening the bolt and installing the external stressing for up lifting the chamber

\section{Conslucion and Suggestion}

\subsection{Conclusion}

The research can be concluded as follows: 
1. The primary defect of bridge element occurs at the embankment, retaining wall, rubber bearing and earth restraint block at the north side of Tuban caused by the surface drainage, excavation in front of the embankment and the flooding of Bengawan Solo River.

2. The overall mark of the bridge is 4 , the retrofitting and replacement of the defect element is needed to restore the bridge condition.

\subsection{Suggestion}

The suggestion for the upcoming research relating to Glendeng Bridge as follows:

1. The model of bridge structure is needed knowing the loading model and predicting the remaining life of the bridge capacity.

2. Structural health monitoring is needed to check the superstructure condition.

\section{REFERENCES}

[1] Tuban Public Work Agency, "Penutupan Jembatan Glendeng," 2020. http://bloktuban.com/2020/12/03/jembatan-glendeng-penghubung-tuban-bojonegorokembali-ditutup-total/.

[2] M. E. Sunaryo, "Ketidakstabilan Timbunan Oprit Jembatan Akibat Dampak Perubahan Tata Guna Lahan dan Pola Aliran Sungai," vol. 1, no. 1, pp. 47-58, 2015.

[3] Bakhtiar, "Penurunan Pelindung Abutment Jembatan Akibat Pengaruh Aliran Turbulensi dan Lokal Scouring pada Uji Model Hidraulik," Bandung, 2013.

[4] Pusjatan, "Pedoman Pemeriksaan Jembatan," Jakarta, Indonesia, 2012.

[5] W. Harywijaya, M. Afifuddin, and M. Isya, "Penilaian Kondisi Jembatan Menggunakan Bridge Management System (BMS) Dan Bridge Condition Rating (BCR)," J. Arsip Rekayasa Sipil dan Perenc., vol. 3, no. 1, pp. 443-451, 2020, doi: 10.24815/jarsp.v3i1.16462.

[6] F. Hariman, H. Christady H., and A. Triwiyono, "Evaluasi Dan Program Pemeliharaan Jembatan Dengan Metode Bridge Management System (BMS) (Studi Kasus: Empat Jembatan Propinsi D.I. Yogyakarta)," Civ. Eng. Forum Tek. Sipil, vol. 17, no. 3, pp. 581593-593, 2007.

[7] Y. Herry, S. M. Nuh, and M. Indrayadi, "Penilaian Kondisi Jembatan Rangka Baja Di Kabupaten Sintang Menggunakan Metode Bridge Manajement System (BMS) (Studi Kasus Jembatan Kapuas III, Kabupaten Sintang)," 2016.

[8] H. Sudradjat, L. Djakfar, and Y. Zaika, "Penentuan Prioritas Penanganan Jembatan Pada Jaringan Jalan Provinsi Jawa Timur ( Wilayah UPT Surabaya : Kota Surabaya , Kabupaten Sidoarjo dan Kabupaten Gresik )," vol. 9, no. 3, pp. 219-228, 2015.

[9] M. Marsuki M., A. Triwiyono, and H. Christady, "Penilaian Kondisi Jembatan Dengan Metode NYSDOT (Studi Kasus 3 Jembatan Di Kota Kendari)," Civ. Eng. Forum Tek. Sipil, vol. 19, no. 1, pp. 1000-1008, 2009.

[10] BMS, "Bridge Management System," Jakarta, 1992. 